\title{
STUDIES REGARDING A VARIETAL ASSORTMENT OF POTTED CHRYSANTHEMUM
}

\author{
M. Cantor ${ }^{1}$, T. Hitter (Buru) ${ }^{1}$, Z. Szekely-Varga' ${ }^{1}$ and E. Buta1*
}

1University of Agricultural Sciences and Veterinary Medicine Cluj-Napoca, Department of Horticulture and Landscaping, Manastur St., No. 3-5, 400372 Cluj-Napoca, Romania.

*Corresponding author email: erzsebet.buta@usamvcluj.ro

\begin{abstract}
Chrysanthemum is one of the major crops in the word and it is grown for two basic ways for cut flowers and potted plants, depending of market demand. In the last years the cultivated areas with Chrysanthemum have gained a significant growth. Also, due to the progress made in the selection of chrysanthemum, in order to obtain valuable varieties grown in pots, knowledge of characteristics morphology has of major importance, and the enrichment of the existing assortment in our country is the main objective of the growers. The flowers occur in various forms, and can be daisy-like, decorative, pompon or buttons. In addition, many colors are available, such as white, yellow, red, purple and green. The present paper aimed to study the main characteristics of Chrysanthemum grown in pots of the following cultivars: 'Vanilla', 'Eté Indien', 'Camina Red', 'Pamplona Jogger White', 'Amelia Jogger', 'Avalon Salmon`. The measurements of the experiment were focused on the vegetative growth of the cultivars listed above (plant diameter, circumferences of the plant, height of plant, number of stems/plant, number of branches/stem, number of flowers/plant and the diameter of the flowers) in order to diversify the current Chrysanthemum assortment and to promote the cultivation of the most valuable cultivars. The obtained results shown that 'Pamplona Jogger White` cultivar registered increases in the case of the diameter, circumference of the plant, and diameter of the flowers. On the opposite side the 'Camina Red' cultivar recorded the largest number of branches/stem and number of flowers/plant and the 'Avalon Salmon' cultivar has the highest values in terms of plant height and number of stems/plant.
\end{abstract}

Keywords: characteristics, mums, potted plants, cultivars, vegetative growth.

\section{INTRODUCTION}

Ornamental plants breeding and cultivation in protected areas offers a great diversity of decorative forms and is an important part of the trade in decorative plants through flowers and leaves (Anton et al., 2007). For more than 2000 years humans have cultivated and improved Chrysanthemum plants. Those belong to the oldest ornamental plants of mankind and are still bred and cultivated in Europe (Halmagyi et al., 2004; Larson, 2012). According to estimates, an important place in the top of flowers grown in protected areas was occupied by the chrysanthemum, one of the most representative plant of gardens and landscape planting design in the autumn season. This is due both to its exceptional decorative qualities and to the autumn plant sale period and market requirements typical from September to December. Due to the diversity of shapes and sizes of the inflorescence, the multitude of colors, its suitability for modern homes, make this flower species to be highly appreciated 
by the general public.

Kitamura (Compositae, Anthemideae), originates from the Greek krus anthemon, meaning gold flower (Fukai, 1995), originally from China and Japan, known since 1500 BC. as a vegetable plant for the consumption of leaves, without a doubt chrysanthemum is considered today 'queen of autumn flowers` (Toma, 2009).

In Europe, the chrysanthemum was cultivated only in 1789, brought from China to France in the form of three varieties, of which only one could be cultivated. The climate of France, provided seed production facilities, allowed the production of various varieties, some of them being preserved even to this day (Rayonnante variety). Under these conditions, the cultivated areas with chrysanthemums expanded both in the field and in greenhouses. Today, the achievements of Europeans in obtaining new varieties, as well as those of improving cultivation technologies are superior to those in the Far East (Barbu, 2008). Also, In Western European countries, the potted chrysanthemum is the traditional plant for decorating graves in late October-early November, when the memory of the deceased is honored (Toma, 2009).

In Romania, chrysanthemum is reported in 1750 as the `autumn daisy`. The first imports of chrysanthemums to be cultivated around Bucharest were made before the First World War, then the assortment increased with the appearance of the first flowers in the capital, Bucharest (1925-1928), gradually numerous flower exhibitions with this species were organized. A significant development in this field is noticed with the establishment of the National Institute of Horticultural Research (1957), when valuable varieties of chrysanthemums were brought to be studied and cultivated for production. Nowadays, chrysanthemums can be admired in landscape arhitecture arrangements or private gardens (Vidrașcu and Teodorescu, 1993), but also in flower shops and floral design using the most cultivated species for the production of cut flowers, both in greenhouse and in the field is Chrysanthemum x hortorum Hort. (Cantor, 2016). Thus, commercial chrysanthemum cultivars are globally important cut flower and pot plant species usually cultivated by vegetative cuttings (da Silva, 2004). As chrysanthemums have a great impact on the flower market, numerous investigations and scientific researches of physiology, biochemistry, genetics, cellular ultrastructure have been undertaken, in order to know their biology and ways to optimize their growth and productivity and control major diseases and pests. An important contribution, in this sense, has been brought by many researchers from abroad (Zhong Yao Cai, 2008). Regarding breeding and cultivation in protected areas, where specific environmental conditions can be created, the chrysanthemum can be grown all year round, enriching the assortment of flowers from all seasons. Flowering through controlled crops at any time of year, ensuring quite a long durability in vases of 10-14 days as a cut flower, the possibility of using it in various bouquets and floral arrangements or as a potted plant recommends chrysanthemum as the most accepted and valued species (Băla, 2012). As cut flowers, chrysanthemums are useful for decorating interiors in the form of arrangements in large and medium vases, with a note of elegance and sobriety. In general, due to the richness of shapes and colors, chrysanthemums combine with each other, but can also be combined with other flowering species, having special effects. As a cut flower or in pots, chrysanthemums can be used on all occasions, all year round (van Meeteren et al., 2003; Whale, 2011; Hunter, 2012; Vahdati et al., 2012; Buta and Cantor, 2015). All these qualities mentioned before, determine a wide use of chrysanthemums: field culture for obtaining cut flowers or for decorating green spaces (parks and gardens), potted plant, culture in protected areas (greenhouses and solariums) for cut flowers, especially due to the fact that this species is present throughout the year, especially in summer until autumn when frosts appear (Vidrașcu and Teodorescu, 1993).

The areas cultivated with this flower being significant in the Netherlands, Belgium, France, 
Colombia, Germany, Italy and Israel (Buta et al., 2013), and based on this fact, chrysanthemums occupying 35\% of the total cutflower production in Japan alone, in accordance that cut flowers are extensively used in Japan: $40 \%$ as gifts, $25 \%$ for commercial facilities, $25 \%$ in domestic use, including religious decorations for Buddhist practices, and $10 \%$ for educational such as flower arrangement or ikebana (Boase et al., 1997; Kagami and Okamura, 1997; da Silva, 2004). Commercial hybridization to improve cultivars continues today in Europe, Asia and America. Selection is based not only on flower shape and color but also suitability of seedlings for year-round flowering programs and for postharvest qualities (Lim and Shin, 2007). In our country, in the recent years can be observed an increasingly significant development of chrysanthemum culture as potted plants for the decoration of green spaces, gardens, courtyards, balconies and terraces, but especially for the fact that in Romania the flower that ensures the decoration of graves on November is chrysanthemum. Today, more and more private producers are focusing on growing chrysanthemums in pots to be used in the fall. In this regard, the preferance of varieties will be provided according to the period in which we want to have pots with well-developed and flowering plants in a proportion of at least $90 \%$ to have a commercial appearance. The high interest of Chrysanthemum cultivars used as cut flowers and pot plants in our country, determined to investigate the new assortiment of Chrysanthemum grow in pot (Băla and Berecici, 2011).

The aim of the present research paper was to observation of the morphological and biological traits of chrysanthemums cultivars as 'Vanilla', 'Eté Indien', 'Camina Red', 'Pamplona Jogger White', 'Amelia Jogger', 'Avalon Salmon' in accordance with the dimensions of the vegetative part of chrysanthemums.

\section{MATERIALS AND METHODS}

The study was perfomed for a period of two years (2018-2019) at the didactic greenhouse of the Floriculture belonging to UASVM Cluj-Napoca (Figure 1). Six cultivars of potted Chrysanthemum plants were used in the present work, arranged in three randomized repetitions. Each repetition consisted in five plants, a total of 15 plants/cultivar: 'Vanilla' vanilla, 'Eté Indien` - orange-yellow, 'Camina Red` - red, `Pamplona Jogger White` - white, 'Amelia Jogger - pink, 'Avalon Salmon` - coral (Figure 2), and the average of the experiment was used as control.

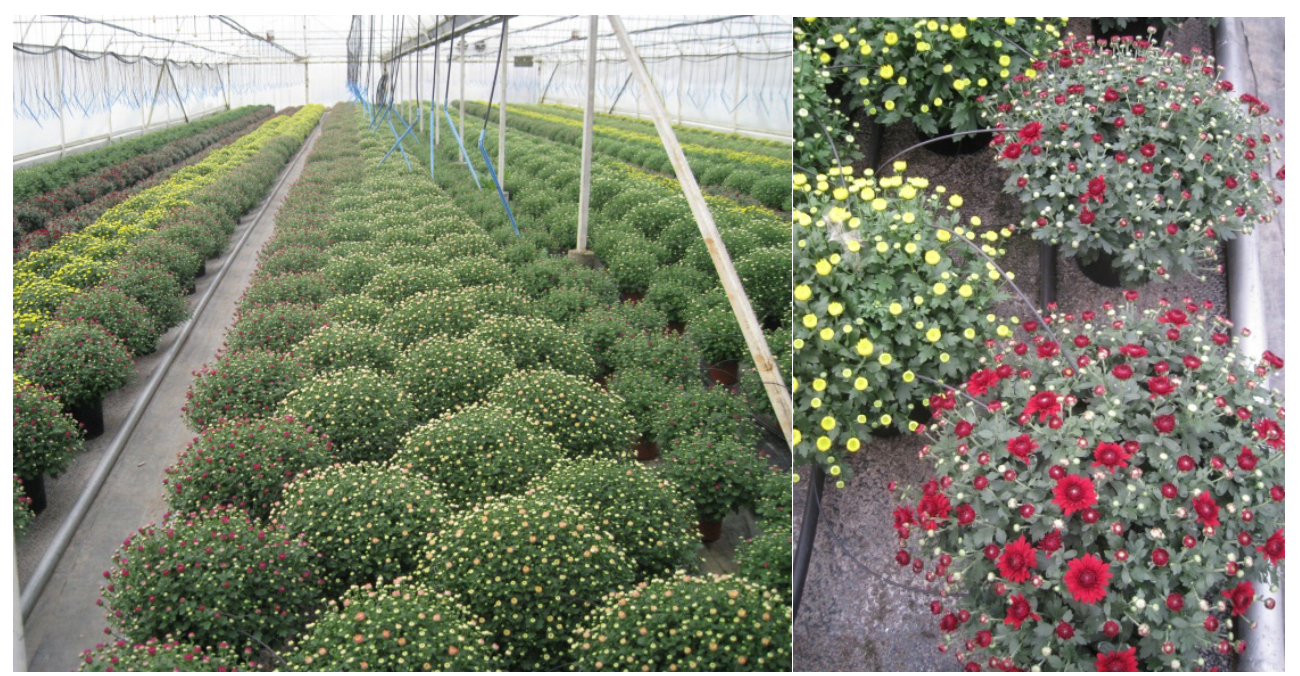

Figure 1. Location of the experiment (Didactical greenhouse at UASVM Cluj-Napoca) 
The potted Chrysanthemum plants subjected in our experiment were numbered from 1 to 90. Regarding the study of plant biology, the following observations and measurements were established: diameter, circumference of the plant, height of plant, number of stems/plant, number of branches/stem, number of flowers/plant and the diameter of the flowers. Periodically chemical treatments were applied against Puccinia chrysanthemi, Oidium chrysanthemi and aphids.

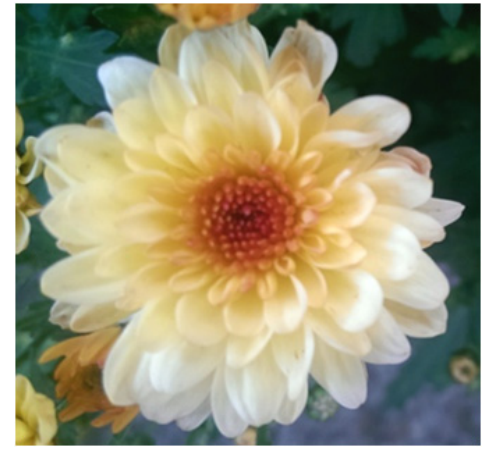

'Vanilla'

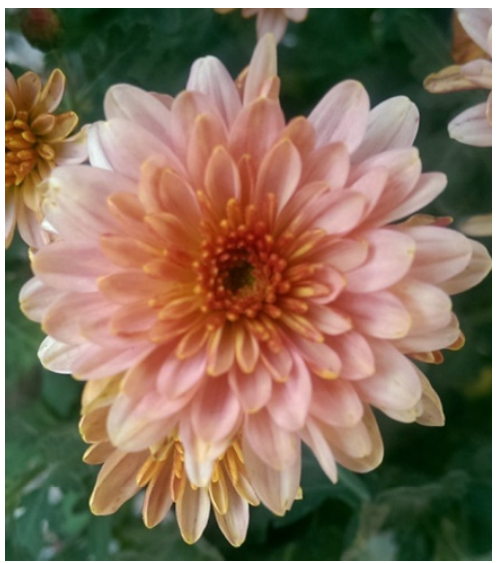

`Avalon Salmon`

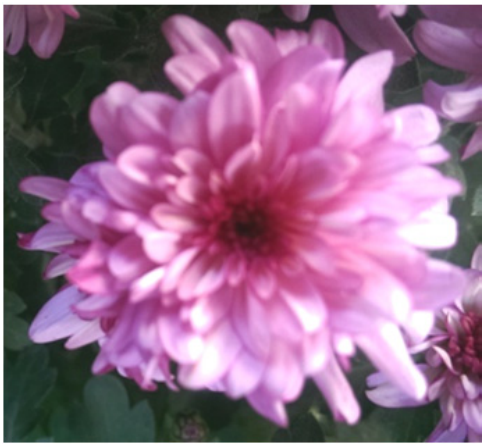

`Amelia Jogger`

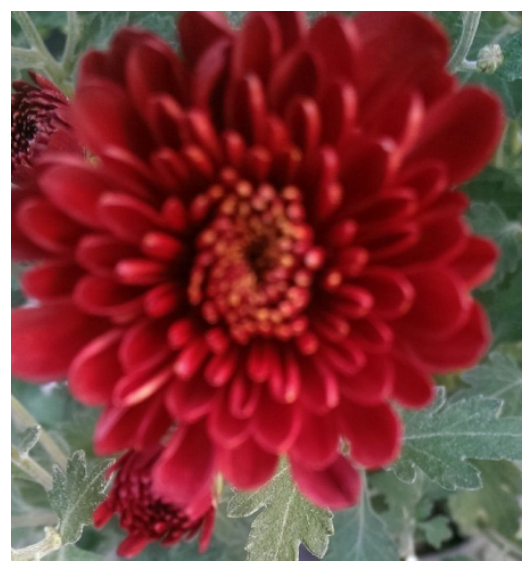

'Camina Red’

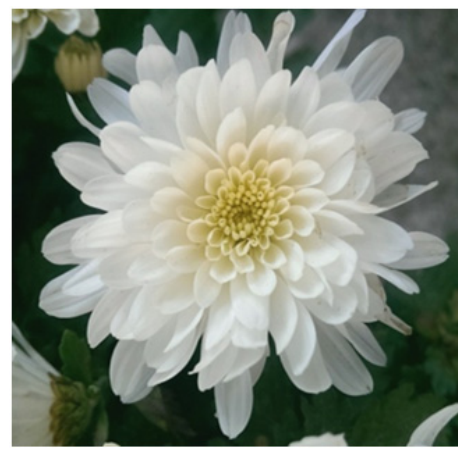

'Pamplona Jogger White`

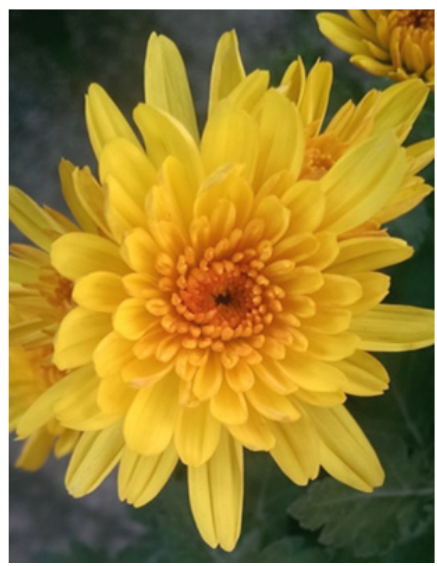

`Eté Indien`

Figure 2. Chrysanthemum cultivars

\section{MATERIALS AND METHODS}

The Chrysanthemum cultivars were planted in three repetitions, according to the randomized block method. The data were interpreted statistically by calculating the average of experience, and the differences between the variants were established by analyzing the variance and using the Duncan test (Ardelean et al., 2005).

In our experiment, observations were made in order to establish the dimensions of the vegetative characteristics of chrysanthemums. The main observations were: diameter of the plant, circumference of the plant, plant height, number of stems/plant. The observations regarding the floral elements were made on number of stems/plant, number of branches/stem, number of flowers/plant and the diameter of the flowers. These observations were made at full maturity of the flowers, not taking into account those previously destroyed. 


\section{RESULTS AND DISCUSSIONS}

To identify the possible differences, measurements were made on the vegetative plant structure and on the vigor of the cultivars, comparing with an average of the character studied on the whole group.

Under our experimental conditions, the highest increase at the diameter of the plants were measured at the 'Pamplona Jogger White' cultivar which was $51.00 \mathrm{~cm}$ and the second was the `Camina Red` with $43.33 \mathrm{~cm}$, which were statistically supported (Table 1). While the `Ete indiene` have registered the smallest increases in the diameter of the plant, which was just $31.00 \mathrm{~cm}$.

Table 1. Diameter of the Chrysanthemum plants

\begin{tabular}{|c|c|c|c|c|c|}
\hline Variants & $\begin{array}{c}\text { Plant } \\
\text { diameter } \\
(\mathrm{cm})\end{array}$ & $\begin{array}{c}\% \\
\text { compared } \\
\text { to control }\end{array}$ & $\begin{array}{c}\text { Differences } \\
\text { compared to } \\
\text { control }\end{array}$ & $\begin{array}{c}\text { Significance } \\
\text { of } \\
\text { differences }\end{array}$ & $\begin{array}{c}\text { Duncan } \\
\text { test }\end{array}$ \\
\hline Average (Control) & 40.50 & 100.0 & 0.00 & Mt. & $\mathrm{A}$ \\
\hline Vanilla & 41.67 & 102.9 & 1.17 & - & $\mathrm{C}$ \\
\hline Ete indiene & 31.00 & 76.5 & -9.50 & 000 & $\mathrm{~A}$ \\
\hline Camina Red & 43.33 & 107.0 & 2.83 & $* * *$ & $\mathrm{D}$ \\
\hline $\begin{array}{c}\text { Pamplona Jogger } \\
\text { White }\end{array}$ & 51.00 & 125.9 & 10.50 & $* * *$ & $\mathrm{E}$ \\
\hline Amelia Jogger & 34.33 & 84.8 & -6.17 & 000 & $\mathrm{~B}$ \\
\hline Avalon Salmon & 41.67 & 102.9 & 1.17 & - & $\mathrm{C}$ \\
\hline
\end{tabular}

The highest increase in the circumference of the shrubs was registered at the 'Pamplona Jogger White' cultivar which was $130 \mathrm{~cm}$, and the smallest circumference was $72.33 \mathrm{~cm}$, measured at the `Ete indiene`Chrysanthemum cultivar (Table 2). The measurements were statistically demonstrated by the Duncan test.

In the case of experimental conditions the smallest growth of mums was registered at the 'Vanilla' cultivar $(24.67 \mathrm{~cm})$, followed by the 'Pamplona Jogger White' with a $26.33 \mathrm{~cm}$ (Table 3). The highest chrysanthemum plant was `Avalon Salmon`cultivar, with a high of $33.67 \mathrm{~cm}$, followed by `Camina Red`cultivar with a difference of just $1 \mathrm{~cm}$.

Table 2. Circumference of the Chrysanthemum cultivars

\begin{tabular}{|c|c|c|c|c|c|}
\hline Variants & $\begin{array}{c}\text { Circumference } \\
\text { of the plant } \\
(\mathrm{cm})\end{array}$ & $\begin{array}{c}\% \\
\text { compared } \\
\text { to control }\end{array}$ & $\begin{array}{c}\text { Differences } \\
\text { compared to } \\
\text { control }\end{array}$ & $\begin{array}{c}\text { Significance of } \\
\text { differences }\end{array}$ & $\begin{array}{c}\text { Duncan } \\
\text { test }\end{array}$ \\
\hline Average (Control) & 99.06 & 100.0 & 0.00 & Mt. & $\mathrm{A}$ \\
\hline Vanilla & 93.67 & 94.6 & -5.39 & 000 & $\mathrm{~B}$ \\
\hline Ete indiene & 72.33 & 73.0 & -26.72 & 000 & $\mathrm{~A}$ \\
\hline Camina Red & 103.67 & 104.7 & 4.61 & $* * *$ & $\mathrm{D}$ \\
\hline $\begin{array}{c}\text { Pamplona Jogger } \\
\text { White }\end{array}$ & 130.00 & 131.2 & 30.94 & $* * *$ & $\mathrm{E}$ \\
\hline Amelia Jogger & 95.33 & 96.2 & -3.72 & 000 & $\mathrm{~B}$ \\
\hline Avalon Salmon & 99.33 & 100.3 & 0.28 & - & $\mathrm{C}$ \\
\hline \multicolumn{7}{|l}{ LSD (p 5\%) 1.68; LSD (p 1\%) 2.39; LSD (p 0.1\%) 3.47 } \\
\hline
\end{tabular}

The 'Avalon Salmon` have registered the most number of stems/plant (10 stems/plant), it was followed by the `Camina Red cultivar with a number of 9 stems/plant (Table 4), the data is statistically supported by the Duncan test. 
Table 3. Chrysanthemum plant height

\begin{tabular}{|c|c|c|c|c|c|}
\hline Variants & $\begin{array}{c}\text { Plant } \\
\text { height } \\
\text { (cm) }\end{array}$ & $\begin{array}{c}\% \\
\text { compared } \\
\text { to control }\end{array}$ & $\begin{array}{c}\text { Differences } \\
\text { compared to } \\
\text { control }\end{array}$ & $\begin{array}{c}\text { Significance } \\
\text { of differences }\end{array}$ & $\begin{array}{c}\text { Duncan } \\
\text { test }\end{array}$ \\
\hline Average (Control) & 29.28 & 100.0 & 0.00 & Mt. & $\mathrm{A}$ \\
\hline Vanilla & 24.67 & 84.3 & -4.61 & 000 & $\mathrm{~A}$ \\
\hline Ete indiene & 30.33 & 103.6 & 1.06 & - & $\mathrm{D}$ \\
\hline Camina Red & 32.67 & 111.6 & 3.39 & $* * *$ & $\mathrm{E}$ \\
\hline Pamplona Jogger White & 26.33 & 89.9 & -2.94 & 00 & $\mathrm{~B}$ \\
\hline Amelia Jogger & 28.00 & 95.6 & -1.28 & - & $\mathrm{C}$ \\
\hline Avalon Salmon & 33.67 & 115.0 & 4.39 & $* * *$ & $\mathrm{E}$ \\
\hline \multicolumn{7}{r}{ LSD (p 5\%) 1.55; LSD (p 1\%) 2.20; LSD (p 0.1\%) 3.18} & \\
\hline
\end{tabular}

Table 4. Number of stems/plant of Chrysanthemum cultivars

\begin{tabular}{|c|c|c|c|c|c|}
\hline Variants & $\begin{array}{c}\text { Number of } \\
\text { stems/plant }\end{array}$ & $\begin{array}{c}\% \\
\text { compared } \\
\text { to control }\end{array}$ & $\begin{array}{c}\text { Differences } \\
\text { compared to } \\
\text { control }\end{array}$ & $\begin{array}{c}\text { Significance of } \\
\text { differences }\end{array}$ & $\begin{array}{c}\text { Duncan } \\
\text { test }\end{array}$ \\
\hline Average (Control) & 7.67 & 100.0 & 0.00 & Mt. & $\mathrm{A}$ \\
\hline Vanilla & 6.00 & 78.3 & -1.67 & 000 & $\mathrm{~A}$ \\
\hline Ete indiene & 7.33 & 95.7 & -0.33 & - & $\mathrm{B}$ \\
\hline Camina Red & 9.00 & 117.4 & 1.33 & $* *$ & $\mathrm{C}$ \\
\hline $\begin{array}{c}\text { Pamplona Jogger } \\
\text { White }\end{array}$ & 7.67 & 100.0 & 0.00 & - & $\mathrm{B}$ \\
\hline Amelia Jogger & 6.00 & 78.3 & -1.67 & 000 & $\mathrm{~A}$ \\
\hline Avalon Salmon & 10.00 & 130.4 & 2.33 & $* * *$ & $\mathrm{D}$ \\
\hline \multicolumn{7}{c}{$\mathrm{LSD}(\mathrm{p} 5 \%) 0.66 ;$ LSD (p 1\%) $0.95 ;$ LSD (p 0.1\%) 1.37} & \\
\hline
\end{tabular}

The number of branches/stem (Table 5) was situated between 5.00 to 9.00 branches per stem. Regarding the number of branches a relative reduction was observed at the the 'Vanilla' cultivar (5.00) compared to the control. Although the highest number of branches/stem was determined at the 'Camina Red' cultivar (9.00) compared to the control.

Table 5. Chrysanthemum number of branches/stem

\begin{tabular}{|c|c|c|c|c|c|}
\hline Variants & $\begin{array}{c}\text { Number of } \\
\text { branches/stem }\end{array}$ & $\begin{array}{c}\text { \% compared } \\
\text { to control }\end{array}$ & $\begin{array}{c}\text { Differences } \\
\text { compared to } \\
\text { control }\end{array}$ & $\begin{array}{c}\text { Significance of } \\
\text { differences }\end{array}$ & $\begin{array}{c}\text { Duncan } \\
\text { test }\end{array}$ \\
\hline $\begin{array}{c}\text { Average } \\
\text { (Control) }\end{array}$ & 7.00 & 100.0 & 0.00 & Mt. & $\mathrm{A}$ \\
\hline Vanilla & 5.00 & 71.4 & -2.00 & 000 & $\mathrm{~A}$ \\
\hline Ete indiene & 6.00 & 85.7 & -1.00 & 00 & $\mathrm{~B}$ \\
\hline Camina Red & 9.00 & 128.6 & 2.00 & $* * *$ & $\mathrm{~F}$ \\
\hline $\begin{array}{c}\text { Pamplona } \\
\text { Jogger White }\end{array}$ & 8.00 & 114.3 & 1.00 & $* *$ & $\mathrm{E}$ \\
\hline Amelia Jogger & 7.33 & 104.8 & 0.33 & - & $\mathrm{D}$ \\
\hline Avalon Salmon & 6.67 & 95.2 & -0.33 & - & $\mathrm{C}$ \\
\hline \multicolumn{7}{|c}{ LSD (p 5\%) 0.58; LSD (p 1\%) $0.82 ;$ LSD (p 0.1\%) 1.17} \\
\hline
\end{tabular}

Considering the number of flowers/plant the best results were obtained at the 'Camina Red cultivar, with an average number of 334.67 flowers/plant. On the opposite side was the 'Vanilla' Chrysanthemum cultivar, with an average number of 93.33 flowers/plant. The results of this measurements were statistically demonstrated (Table 6.). 
Table 6. The number of flowers/plant of Chrysanthemum cultivars

\begin{tabular}{|c|c|c|c|c|c|}
\hline Variants & $\begin{array}{c}\text { Number of } \\
\text { flowers/plant }\end{array}$ & $\begin{array}{c}\% \\
\text { compared } \\
\text { to control }\end{array}$ & $\begin{array}{c}\text { Differences } \\
\text { compared to } \\
\text { control }\end{array}$ & $\begin{array}{c}\text { Significance of } \\
\text { differences }\end{array}$ & $\begin{array}{c}\text { Duncan } \\
\text { test }\end{array}$ \\
\hline Average (Control) & 201.72 & 100.0 & 0.00 & Mt. & $\mathrm{A}$ \\
\hline Vanilla & 93.33 & 46.3 & -108.39 & 000 & $\mathrm{~A}$ \\
\hline Ete indiene & 211.67 & 104.9 & 9.94 & - & $\mathrm{D}$ \\
\hline Camina Red & 334.67 & 165.9 & 132.94 & $* * *$ & $\mathrm{E}$ \\
\hline $\begin{array}{c}\text { Pamplona Jogger } \\
\text { White }\end{array}$ & 192.33 & 95.3 & -9.39 & - & $\mathrm{C}$ \\
\hline Amelia Jogger & 170.67 & 84.6 & -31.06 & 00 & $\mathrm{~B}$ \\
\hline Avalon Salmon & 207.67 & 102.9 & 5.94 & - & $\mathrm{D}$ \\
\hline & $\mathrm{LSD}(\mathrm{p} 5 \%) 15.31 ;$ LSD (p 1\%) 21.77 ; LSD (p 0.1\%) 31.52 & \\
\hline
\end{tabular}

When comparing the mumscultivars flowers diameter, an increase can be observed at the 'Pamplona Jogger White', with an average of $5.57 \mathrm{~cm}$, on the opposite side the 'Amelia Jogger' cultivar was placed, with an average diameter of $3.13 \mathrm{~cm}$. In Table 7 it can be observed that between the cultivars there are statistically significant differences reported, however the diameters are almost similar at each cultivar.

Similar results regarding the morphological characteristics were obtained by calvalho et al.(2020), at the mini chrysanthemum varieties. According to uddin et al., (2015) and ona et al., (2015) the chrysanthemum cultivars showed a wide range of growth and flowering characteristics, which are preferable traits and objectives for the breeders. There are strong evidence that morphological parameters clearly indicate disticntness among the mums varieties (banerji et al., 2012; suvija et al., 2016), like shrubs diameter; circumferences of the shrubs; shrubs height; increment in the number of stems/plant, branches/stem, flowers/plant; diameter of the flowers.

Table 7. Flowers diameter of the Chrysanthemum cultivars

\begin{tabular}{|c|c|c|c|c|c|}
\hline Variants & $\begin{array}{c}\text { Diameter of } \\
\text { the flowers } \\
(\mathrm{cm})\end{array}$ & $\begin{array}{c}\% \\
\text { compared } \\
\text { to control }\end{array}$ & $\begin{array}{c}\text { Differences } \\
\text { compared to } \\
\text { control }\end{array}$ & $\begin{array}{c}\text { Significance } \\
\text { of } \\
\text { differences }\end{array}$ & $\begin{array}{c}\text { Duncan } \\
\text { test }\end{array}$ \\
\hline Average (Control) & 4.46 & 100.0 & 0.00 & Ct. & $\mathrm{A}$ \\
\hline Vanilla & 4.13 & 92.7 & -0.33 & 00 & $\mathrm{~B}$ \\
\hline Ete indiene & 5.27 & 118.1 & 0.81 & $* * *$ & $\mathrm{D}$ \\
\hline Camina Red & 4.27 & 95.6 & -0.19 & 0 & $\mathrm{BC}$ \\
\hline Pamplona Jogger White & 5.57 & 124.8 & 1.11 & $* * *$ & $\mathrm{E}$ \\
\hline Amelia Jogger & 3.13 & 70.2 & -1.33 & 000 & $\mathrm{~A}$ \\
\hline Avalon Salmon & 4.40 & 98.6 & -0.06 & - & $\mathrm{C}$ \\
\hline \multicolumn{7}{l}{} \\
\hline
\end{tabular}

\section{CONCLUSIONS}

Based on the present study results can conclude that:

The diameter of the plants registered the highest value at the 'Pamplona Jogger White` cultivar, and the lowest at 'Ete indiene`. In the term of the plant circumferences the highest was determined at the `Camina Red` and 'Pamplona Jogger White` cultivars. In the case of the plant height `Avalon Salmon` have registered the biggest growth, followed by `Camina Red'. The results concerning the number of stems/plant `Avalon Salmon` showed higher increases compared to the other cultivars. The cultivar 'Camina Red' recorded the most 
increses in the number of branches/stem. `Pamplona Jogger White` was the chrysanthemum cultivar with the highest flower diameter observed in the experiment.

The data presented above shown that the 'Pamplona Jogger White` and 'Camina Red are the most productive and decorativecultivars of those studied. The potted chrysanthemum cultivars which showed higher morphological characteristics are recommended to be promoted and cultivated in the Romanian area, and due to this the mums breeders have a wide range of choices to make.

\section{REFERENCES}

1. Anton Doina, Carmen Nicu \& Manuela Manda (2007). Floricultură specială. Ed. Universitaria Craiova, 12-15.

2. Ardelean M., Sestras R., Cordea M. (2005). Tehnica experimentală horticolă, Ed. AcademicPres, Cluj-Napoca: 61-67.

3. Băla Maria (2012). Floricultură generală și specială. Ed. Partos Timișoara, 303-306.

4. Băla Maria, Berecici D.N. (2011). The behavior of some new chrysanthemum cultivars (Chrysanthemum indicum L.) cultivated in pots, in greenhouse conditions. JOURNAL of Horticulture, Forestry and Biotechnology, 15(2), 15-18.

5. Banerji B.K., Batra A. \& Dwivedi, A.K. (2012). Morphological and biochemical characterization of chrysanthemum. Journal of Horticultural Sciences, 7(1), 51-55.

6. Barbu M. (2008). Cercetări privind sistemul de fertilizare complexă în tehnologia de conducere la Chrysanthemum sp. BA, Teza de doctorat USAMV Bucuresti.

7. Boase M.R., Miller R., Deroles S.C. (1997). Chrysanthemum systematics, genetics, and breeding. Plant breeding reviews (USA).

8. Buta Erzsebet, Cantor Maria (2015) Manual didactic: Artă Florală. Ed. AcademicPres.

9. Buta Erzsebet, Cantor Maria, Buta M. \& Horţ Denisa (2013), Multiplication and shaping of Chrysanthemum varieties cultivated in pots. Journal of Horticulture, Forestry and Biotechnology, Volume 17(1): 99-103.

10. Cantor Maria (2016). Floricultură specială. Ed. AcademicPres Cluj-Napoca, 124-127.

11. Carvalho C.R.V.D., Santos M.N.D.S. \& Mapeli A.M. (2020). Morphophysiological characterization of leaves and inflorescences of commercial mini chrysanthemum varieties. Ornamental Horticulture, 26(2), 277-282.

12. da Silva J.A.T. (2004). Ornamental chrysanthemums: improvement by biotechnology. Plant Cell, Tissue and Organ Culture, 79(1), 1-18.

13. Fukai S. (1995). Cryopreservation of germplasm of chrysanthemums. In Cryopreservation of Plant Germplasm I Springer, Berlin, Heidelberg. Springer-Verlag, Berlin, 447-457.

14. Halmagyi A., Fischer-Klüver G., Mix-Wagner G. \& Schumacher, H.M. (2004). Cryopreservation of Chrysanthemum morifolium (Dendranthema grandiflora Ramat.) using different approaches. Plant Cell Reports, 22(6), 371-375.

15. Hunter Norah T. (2012). The art of floral design. Cengage Learning.

16. Kagami Y., Okamura M. (1997) Flower production in Japan and agribio business and technology of Kirin: a case in private sector approach. In: Watanabe K \& Pehu E (eds). Plant Biotechnology and Plant Genetic Resources for Sustainability and Productivity, 173-181.

17. Larson R.A. (Ed.). (2012). Introduction to floriculture. Elsevier.

18. Ona A.F., Roni M.Z.K., Ahmad, H., Jui, N.J. \& Uddin, A.F.M.J. (2015). Study on growth and flower yield of five Snowball varieties. Bangladesh Research Publication Journal, 11(3), 182-186.

19. Suvija N.V., Suresh, J., Kumar, R.S. \& Kannan M. (2016). Evaluation of chrysanthemum (Chrysanthemum morifolium Ramat.) genotypes for loose flower, cut flower and pot mums. Int $\mathrm{j}$ innov res adv stud (IJIRAS), $3(4), 100-104$.

20. Toma F. (2009). Floricultură și artă florală. Specii utilizate pentru producerea florilor tăiate. Ed.. INVELMultimedia București, Vol. 2: 29-30, 42-45.

21. Uddin A.F.M.J., Taufique T., Ona A.F., Shahrin S. \& Mehraj, H. (2015). Growth and flowering performance evaluation of thirty-two chrysanthemum cultivars. Journal of Bioscience and Agriculture Research, 4(01), 40-51.

22. Vahdati M.N., Tehranifar A., Bayat H. \& Selahvarzi Y. (2012). Salicylic and citric acid treatments improve the vase life of cut chrysanthemum flowers. J. Agr. Sci. Tech., Vol. 14: 879-88.

23. van Meeteren U., van Gelder A., van Ieperen W. (2003, August). Effect of growth conditions on post harvest rehydration ability of cut chrysanthemum flowers. In VIII International Symposium on Postharvest Physiology of Ornamental Plants 669, 287-296.

24. Vidrașcu Profira, Georgeta Teodorescu (1993). Crizantema. Ed. Ceres București, 99-105.

25. Whale Susan (2011). Cut Flowers: A Practical Guide to Their Selection and Care. Ed. Jago.

26. Zhong Yao Cai, Gao M.H., Li H., Zhang L., Xiao S.X. (2008). Studies on chemical constituents from flowers of Chrysanthemum indicum May:31(5):682-684. 